\title{
A Tax Evasion - Bribery Game: Experimental Evidence from Ukraine
}

\author{
Volodymyr Bilotkach ${ }^{1}$ \\ University of California, Irvine, Department of Economics
}

\begin{abstract}
This paper examines the issue of tax evasion by enterprises through underreporting activity. We develop a view of this phenomenon as an equilibrium of the game between a businessman and an imperfectly monitored supervising official, in which a businessman can hide part of his profit and offer bribe to official. We determine conditions under which such tax evasion and bribery become wide-spread in the society, resulting in shadow economy. The game is put into an experimental setting in Kiev, Ukraine, with the emphasis of spreading of the tax evasion and bribery activity in the laboratory setting. We find that once it becomes known that substantial share of subjects playing the role of supervising officials agree to accept bribes from subjects playing the role of businessmen, the latter offer bribes more aggressively. Yet, this in turn does not affect the behavior of subjects playing the role of supervising officials.
\end{abstract}

JEL Classification: C91, D73, H26, H32

Keywords: Tax Evasion, Bribery, Experiment, Learning in Games

\section{Introduction}

The extent and persistence of the underground economic activities in many developing and transition countries suggest some fundamental problems. Schneider and Enste (2000), providing the most recent thorough assessment of the extent of shadow economy throughout the world suggest the following numbers in 1994-1995 as percentage of GDP: $39 \%$ in developing countries, 35\% in countries of the former Soviet Union, and $20.9 \%$ in Eastern Europe.

One most commonly used definition of the term 'shadow economy', according to Schneider and Enste (2000, p. 78), is 'all economic activities that contribute to the officially calculated (or observed) gross national product but are currently unregistered'. Shadow or underground economic activities in general can be divided into illegal activities and unreported legal activities. The major point that distinguishes shadow economy in developing and transition countries from that in the developed world is that the unreported and/or underreported legal activities appear much more wide-spread in the former group of countries, as documented (for transition countries) by Johnson et al. $(1997,1998)$.

\footnotetext{
1 Address: 3151 Social Science Plaza, Irvine, CA, 92697, USA. Phone: (949)-824-5192. E-mail: vbilotka@,uci.edu. The author thanks Arthur Schramm and Jim Cox for comments on the theoretical part of the paper and seminar participants at the Central European University in Budapest for useful insights on the previous version of the manuscript. Editors and anonymous referees provided very useful comments. I also thank the Economics Research and Outreach Center (EROC) in Kiev, Ukraine for financial support for this experiment. Assistance of the EERC-Kiev in providing facilities needed to run the experiment is also acknowledged. I am the only person responsible for any remaining errors and omissions. The views described in this paper are the author's and must never be claimed or interpreted to represent the position of the Economics Education and Research Consortium (EERC) or any of its members.
} 
The generally accepted reason for emergence and sustainability of such underreporting in developing and transition countries is avoiding high taxes. The prohibitively high tax rates are claimed to force firms to hide their activity in the shadow'. Johnson et al. (1999) also suggest the following causes for unreported activity: predatory behavior of government officials; escaping extortion by criminal gangs; and inadequacy of institutional environment (i.e., weak contract enforcement).

In either case, businesses are mostly viewed as victims of government officials or criminal structures, acting at their discretion. This paper develops a different view at underreporting as a Nash equilibrium of a game played between a government official and a businessman. The game itself resembles the traditional tax evasion game. The payoff structure is developed taking into account certain widely recognized institutional features of developing and transition economies, such as low compensation and imperfect monitoring of the government officials. Analysis of the model suggests a possibility that businesses may choose to underreport their profit and offer bribes to the government official because the official's best response to such action is accepting the bribe. Further analysis of the model suggests that underreporting will most easily spread across the society when share of officials willing to accept bribes reaches certain level, after which share of businessmen hiding profit will start increasing.

The model was put in the experimental setting. The experiment was run in Kiev, Ukraine, in November of 2004. In order to add an element of learning to the experiment, the number of subjects playing the role of officials willing to accept bribes in the preceding round was periodically announced. The underlying theoretical model predicts that the share of businessmen hiding profit (and offering bribes) will increase once the share of officials accepting bribes has reached certain threshold. On the other hand, more officials should be willing to accept bribes if there are businesses hiding profit. Interestingly enough, in our experiment we found support for the first theoretical prediction but not for the second one. This could suggest that subjects playing the role of businessmen were more responsible for emergence of the shadow economy in the experimental setting. Alternatively, this observation could be driven by the fact that no messages on the number of businessmen hiding profit were sent to the subjects.

The idea of possible 'conspiracy' between tax payers and monitoring officials is a rather obvious one. Thus, several papers have suggested models of such an interaction. Chander and Wilde (1992) suggest that in presence of corrupted officials tax returns will be audited more frequently. Moreover, when tax evaders are willing to offer bribes to corrupt officials, their model also implies that increases in fines or tax rates may lead to lower expected government revenue (even though this result does not appear frequently in their model). Polinsky and Shavel (2001) study how much resources need to be allocated to detection of bribery, as well as the optimal structure of fines. They suggest (not surprisingly) that corruption deterrence activity is necessary even if it fails to completely deter the undesirable activity. Acconcia et al. (2003) develop a setup which suggests that while tougher deterrence policy and higher fines can lead to less tax evasion, it will not necessarily reduce corruption amongst officials. Blackburn and Forgues-Puccio (2005) suggest a model in which there is a possibility of conspiracy between taxpayers and bureaucrats, due to the fact that some officials are exogenously determined to be corruptible. The authors suggest that resulting tax evasion leads to higher inequality in the society, confirming the empirical finding that higher corruption 
is associated with higher inequality. All these papers are theoretical, and I am not aware of attempts to put these models into an experimental setting.

There is large experimental tax compliance literature, well surveyed by Torgler (2002). The survey suggests that while lower tax rate, higher chance of auditing and bigger fines all positively affect compliance, it is also true that social and institutional factors systematically matter.

The studies of tax evasion in transition countries include Gërxhani and Schram (2006), Gërxhani (2004), Gërxhani and Kuiper (2004), and Trehub (2004). The former is an experimental study of individual incentives for tax evasion in Albania and the Netherlands. One of the rather surprising findings of this work is that in the laboratory environment Dutch people tend to avoid taxes more frequently than Albanians. Gërxhani (2004) provides a test of (and finds support for) the Feige's (1997) conjecture that the major source of informal economic activities in transition is the clash between the formal and informal institutions. She examines household survey data on tax evasion in Albania. Gërxhani and Kuiper (2004) find that women in Albania tend to evade taxes less than men do. Trehub (2004) studies effect of changes in the Russian personal income tax law (effectively lowering the personal income tax rate) on individual tax evasion, using the Russian Longitudinal Monitoring Survey (RLMS) data. He finds that people with income below the certain threshold (approximately $\$ 170$ a month) started evading taxes more, while for people with incomes above that threshold the level of tax evasion did decrease following reduction in the personal income tax rate.

As far as bribery is concerned, obvious reasons prevent a thorough empirical investigation, especially in transition economies. Yet, Johnson et al. (1999) report results of survey of enterprises in five transition economies (Ukraine, Russia, Poland, Slovak Republic and Romania). Authors find that over $87 \%$ of Ukrainian and $91 \%$ of Russian respondents claim to be paying bribes to government officials; whereas for other countries included into the survey the numbers are $19.3 \%$ for Poland, $42,2 \%$ for Slovak Republic and 17\% for Romania. The most notable experimental bribery papers are Abbink et al. (2002) and Abbink and Hennig-Schmidt (2002). ${ }^{2}$ Both study bribery in the context of trust-and-reciprocity game (a subject being offered a bribe for otherwise punishable activity can either keep his/her promise and engage in this activity or keep the money and do nothing; in our setup, a subject being offered a bribe does not have such an option).

This paper is the first one linking phenomena of tax evasion and bribery in a simple experimental setting. We also conjecture that this link (under certain 'favorable' institutional environment which includes imperfect monitoring and low compensation of government officials) may be partly responsible for emergence and sustainability of the shadow economic activity.

Our study does have some important limitations. First of all, the game we offer is more likely to be representative of a situation faced by small and middle-sized businesses. High-profile corruption involving large enterprises often involves other activities (such as lobbying and kickbacks) which are outside of the scope of our analysis. Second, our experimental setup differs from the naturally occurring situation in several ways. However, these differences most likely work against our results, as will be discussed below. Third, we only consider a single set of parameter values: yet, there is a reason to believe that this set is roughly representative of the naturally occurring

\footnotetext{
${ }^{2}$ Here we talk about setups in which subjects offer bribes or other payments to each other for otherwise punishable activity
} 
setup of Ukrainian economy at the time the experiment was run. Last but not least, we suggest a different view (not the different view) of the phenomenon under consideration; we acknowledge that the traditionally held belief (suggesting firms are victims) could as well be correct.

The rest of the paper is organized as follows. Section II describes the theoretical model. Setup of the experiment is discussed in Section III. Section IV presents results, and Section V concludes. Experiment related materials (instructions and subject sheets) are in the Appendices.

\section{Model}

This section presents a game between a businessman and a supervising/controlling government official. We will denote businessman's payoff function by $u()$ and official's by $v()$. The game is somewhat similar to the textbook examples of inspection (e.g., Fudenberg and Tirole, 1991) or tax evasion (e.g., Gardner, 1995) game. However, the structure of payoffs will be somewhat different from the textbook examples, which will stipulate different Nash equilibria in our model.

The strategies and payoffs are as follows. The businessman receives profit ${ }^{3}$ $\pi>0$ and faces flat tax rate $0<t<1$. However, the businessman can choose to either hide part of his profits (strategy $\mathrm{H}$ ) or disclose the profit truthfully (strategy $\mathrm{NH}$ ). That is, the profit is decomposed into the 'disclosed' and 'hidden' parts, so that:

$$
\pi=\pi_{D}+\pi_{H}
$$

Businessman's payoff will depend not only on the share of profit he chooses to hide, but also on the strategy chosen by the supervising official, who always inspects the business. That is, unlike in the inspection game, where worker could either work or shirk and inspector could choose whether or not to monitor him, here the businessman knows that he will be inspected. ${ }^{4}$

In the course of inspection the official perfectly observes actual profit, and can choose either to "cooperate" (strategy C) or "not cooperate" (strategy NC) with the businessman. The former case involves accepting from the businessman a bribe in the amount $b<t \pi_{H}$. We effectively assume that once the businessman decides to hide his profit, he simultaneously decides to offer bribe to the supervising official. However, if the official chooses not to cooperate with the businessman hiding part of his profit, the hidden profit gets confiscated, ${ }^{5}$ and the businessman's payoff will be $u(H, N C)=(1-t) \pi_{D}$.

The official receives base salary $w$, and faces (small) probability that his/her accepting a bribe will be discovered. If this happens, we assume that the official will be fired. ${ }^{6}$ In case the businessman decides not to hide his profit the official gets $w$ (base salary) whether or not he intends to cooperate with the entrepreneur. If the official

\footnotetext{
3 Adjusting for the money hidden in the 'legal' way (that is, using loopholes in the legislation).

4 Anecdotal evidence from transition economies (especially Ukraine and Russia) suggests that businesses are indeed inspected very often.

${ }^{5} \mathrm{~A}$ more frequently applied penalty is confiscation of the tax owed plus application of a fine.

${ }^{6}$ Even though accepting a bribe is often considered a criminal offense, in transition and developing countries the chance a dishonest official will be imprisoned does not appear very high
} 
cooperates and businessman decides to hide his profit, then the official's expected payoff is:

$$
v(H, C)=(1-p)(b+w)
$$

where $\mathrm{p}$ is the probability of getting caught. In case of businessman hiding output and official not cooperating, we still assume that the official only obtains his salary. The description above suggests the following representation of the game in the normal form.

Table 1: Game in the Normal Form

\begin{tabular}{|c|c|c|c|}
\hline & \multicolumn{2}{|l|}{ Official } \\
\hline & & Cooperate & $\begin{array}{r}\text { Not } \\
\text { Cooperate }\end{array}$ \\
\hline \multirow{2}{*}{ essman } & Hide & $\begin{array}{l}(1-t) \pi_{D}+\pi_{H}-b ; \\
(1-p)(b+w)\end{array}$ & $w \quad(1-t) \pi_{D}$ \\
\hline & $\begin{array}{ll} & \text { Not } \\
\text { Hide } & \end{array}$ & $(1-t) \pi ; w$ & w $\quad(1-t) \pi$ \\
\hline
\end{tabular}

From the simple analysis of the above game matrix we can state that the game can have either one or two Nash equilibria in pure strategies. If the following inequality holds:

$$
p>\frac{b}{b+w}
$$

then the only Nash equilibrium of this game will be (Not Hide; Not Cooperate). If the above inequality does not hold, then we will have two equilibria in pure strategies: (Hide; Cooperate) and (Not Hide; Not Cooperate). Holding amount of bribe constant, the two equilibria case is more likely, the lower the official's wage and the lower the probability of being caught. It is also interesting to note the following about the case of two Nash equilibria. Once we change the structure of the game from simultaneous to sequential one, only the (Hide; Cooperate) strategy profile will be the subgame perfect equilibrium. The relevant analysis is trivial.

Let us work with the simultaneous version of the game. Since this game is played between businessmen and officials all across the society, it makes sense to examine the process of learning in this game to determine conditions, under which this kind of cooperation between businessmen and officials may become wide-spread. The following exercise presents examination of the replicator dynamics of our 'system'.

Let $x$ denote percentage of businessmen playing "Hide" strategy. Then percentage of entrepreneurs playing "Not Hide" strategy will be $(1-x)$. Denote by $y$ share of officials playing "Cooperate" strategy. Using these notations, we can write replicator equations describing changes in $\mathrm{x}$ and $\mathrm{y}$ over time as follows:

$$
\frac{d x}{d T}=x[u(H)-\operatorname{average}(u)]
$$




$$
\frac{d y}{d T}=y[v(C)-\operatorname{average}(v)]
$$

where $T$ is time; $u(H)$ is the businessman's expected payoff from playing "Hide" strategy; average $(u)$ and average $(v)$ stand for the average payoff across the populations of businessmen and officials, respectively; and $v(C)$ is the official's expected payoff from playing "Cooperate" strategy.

For the businessman we have the following:

$$
u(H)=\left[(1-t) \pi_{D}+\pi_{H}-b\right] y+\left[(1-t) \pi_{D}\right](1-y)
$$

and

$$
\operatorname{average}(u)=x u(H)+(1-x)(1-t) \pi
$$
written as:

after some rearrangement, the replicator equation for businessmen can be

$$
\frac{d x}{d T}=x(1-x)\left[y\left(\pi_{H}-b\right)-(1-t) \pi_{H}\right]
$$

clearly, $\frac{d x}{d T}>0$ (which is equivalent to increasing share of businessmen playing "Hide" strategy) if the term in the square brackets in (8) is greater than zero, which is true when the following inequality holds:

$$
y>\frac{(1-t) \pi_{H}}{\pi_{H}-b}
$$

Thus, once share of bribe-taking officials exceeds certain value, as determined by (9), the share of profit-hiding entrepreneurs will tend to increase. Note that this cut-off share negatively depends on the tax rate and positively - on the amount of bribe. This relationship is intuitive. Further, (8) implies two potentially dynamically stable shares of profit-hiding businessmen in our set-up: zero and one. The stability theorem ${ }^{7}$ (e.g., Gardner, 1995, p. 210) can be applied here to see that $x=0$ will be a dynamically stable solution if (9) does not hold, while otherwise $x=1$ will be dynamically stable. following:

Let us now analyze the replicator equation for officials. We obtain the

$$
\begin{aligned}
& v(C)=(1-p)(b+w) x+w(1-x) \\
& \operatorname{average}(v)=y v(C)+(1-y) w
\end{aligned}
$$

which, after some rearrangement, yields:

$$
\frac{d y}{d T}=y(1-y) x[b-p(b+w)]
$$

The share of 'cooperating' officials will be increasing if the following holds true: $x>0$; and

\footnotetext{
${ }^{7}$ This theorem tells in our case that root of the right-hand side of (8) - obtained by equating the RHS to zero - will be dynamically stable if first derivative of the RHS with respect to $\mathrm{x}$ evaluated at the value of the root is negative.
} 


$$
p<\frac{b}{b+w}
$$

however, (14) is precisely the condition necessary for existence of the two Nash equilibria in pure strategies. Again, the stability theorem suggests that $y=1$ will be a dynamically stable share of bribe-accepting officials if (14) holds $(y=0$ is dynamically stable otherwise).

It is however not easy to say which of the two equilibria will become widespread in the society. On one hand, as long as there are businessmen hiding profit, the share of officials willing to take bribes will be increasing. On the other hand, unless share of officials taking bribes has reached certain threshold, the share of profit-hiding businessmen will tend to zero. Generally speaking, how far the Nash equilibrium involving profit hiding and bribery will spread will depend on where we will start in terms of shares of profit-hiding businessmen and bribe accepting officials.

The model presented in this section is necessarily simplistic, yet it includes some of the most important stylized characteristics of relationships between the businesses and the enforcement officials. We can say that our model puts part of the blame for underreporting of business activity on businessmen. Namely, our model shows that hiding profit can be the businessman's best strategy under certain circumstances.

One might suggest that our model is not entirely realistic as it deliberately excludes the possibility that the enforcement official can have more 'bargaining power' in the process of inspecting a business, and may thus attempt to extort the bribe even if the businessman reports his profit truthfully. Such scenario is indeed possible, when the official is either myopic or well monitored but not punished severely (e.g., gets fired but keeps all the income received as bribes). Hiding profit would be a businessman's rational response to such a situation, and in this case he would not strictly speaking bear the blame for the shadow economy that emerges as a result. Johnson et al. (1999) suggest that extortionate behavior is characteristic of government officials in transition economies, but this conclusion is based on businessmen's responses, and one will be reluctant to admit he has paid the bribe because it was beneficial for him to do so when he can answer he's been robbed. What we indeed do with our model is suggesting a scenario making both officials and businessmen responsible for emergence and persistence of the shadow economy, while admitting that the generally accepted view may also be true.

\section{Experiment - Setup}

To test our model in laboratory setting, an experiment was set up and run in Kiev, Ukraine, on November 13, 2004. The experiment was conducted on the premises of the Economics Education and Research Consortium's (EERC) Master of Arts Program in Economics at the National University of Kiev-Mohyla Academy (NaUKMA). The experiment was a part of the EERC annual student conference. Sixteen subjects voluntarily participated in the experiment. The subjects were

\footnotetext{
8 The experiment was included into the conference program as 'A Special Session on Experimental Economics', scheduled in the morning of the second day of the conference. The participation was voluntary.
} 
conference participants and students of the EERC MA Program in Economics. ${ }^{9}$ The experiment was conducted in English, although all subjects were nationals of Ukraine, Belarus and Moldova. English is the language of instruction at the EERC MA Program, as well as the language of the EERC annual student conference, so insufficient knowledge of language by the subjects was not a matter of concern. We should note that we decided to run this experiment during the conference in part since this gave us more assurance that the subjects did not know each other very well, which would be harder to achieve had we involved only EERC MA Program students, many of whom live in the same dormitory and communicate on daily basis.

The experimental setup closely followed the game, described in the previous section of this paper. The parameter values have been set as follows. Total profit was equal to ten experimental hryvnias. ${ }^{10}$ A subject playing the role of a businessman had an option to hide 50 percent of his profit. This value was taken to represent the widespread belief in the Ukrainian society (supported by some estimates) that about half of the country's economy was in the shade.

The tax rate was set at 50 percent of the reported profit (which roughly represented the estimated tax burden on entrepreneurs in Ukraine at the time). The salary of the tax official was set at one experimental hryvnia, a low level compared to the businessman's profit. The amount of bribe was set at one experimental hryvnia, and the probability that bribe-taking will be disclosed was set at 0.1 - again, a rather small number.

Following the theoretical model, the experiment stipulated that should the businessman try to hide part of his profit and the official choose not to cooperate, the hidden part of profit will be confiscated. The parameter values used in the experiment imply the following payoff matrix.

Table 2: Payoff Matrix of the Experiment

\begin{tabular}{|c|c|c|c|}
\hline & \multicolumn{2}{|l|}{ Official } \\
\hline & & Cooperate & Not Cooperate \\
\hline \multirow{2}{*}{ Busine } & Hide & $6.5 ; 1.8$ & $2.5 ; 1$ \\
\hline & Not & $5 ; 1$ & $5 ; 1$ \\
\hline
\end{tabular}

This game clearly has two Nash equilibria in pure strategies: (Hide; Cooperate) and (Not Hide; Not Cooperate). Number of businessmen choosing to hide their profit should start increasing once (according to (9)) share of officials who cooperate (accept bribes) exceeds 0.625 (or, five out of eight officials participating in an experiment).

The experiment was conducted as follows. First, the subjects entered auditorium and were asked to choose a place either on the right- or the left-hand side of the room. Then it was announced that subjects on the right-hand side of the room would be playing the role of businessmen and those on the left-hand side would play the role of government officials. No switching of places was allowed after this announcement. The subjects had no prior knowledge which side will be playing which

\footnotetext{
${ }^{9}$ We did not notice substantial differences in behavior across the two groups. In fact, since both outside conference participants and 'local' MA students are economists, this was to be expected.

${ }^{10}$ Hryvnia is the national currency of Ukraine. At the time the experiment was conducted, the exchange rate of hryvnia to US dollar was 5.32 hryvnias per dollar, and the average monthly salary in Ukraine was close to 600 hryvnias.
} 
role. Nor did they know the nature of the experiment until the instructions were handed out.

Experiment instructions (Appendix A) were then distributed and read aloud to all subjects. This means that those playing the role of businessmen heard the officials' instructions, and vice versa. Clarifying questions were answered, each subject was assigned a number, and subject sheets (Appendix B) have been distributed. Twelve experimental rounds were conducted. At the end of each round subject sheets were collected, and each official was randomly matched with a businessman to determine the players' payoffs. Should (Hide; Cooperate) strategy profile has been encountered; a random draw decided whether the transaction has been discovered.

To introduce possibility of learning, the number of officials, who in the latest round chose to accept payment if offered, was announced after the fourth and the eighth rounds. Note that the subjects had no prior knowledge that such announcements would be made. The announcements were made to both businessmen and officials. We felt such announcements were necessary, as replicator dynamics introduced in Section II stipulate that players adjust their behavior by comparing their payoff to that of an average player of the same type. By observing only their own payoffs, subjects would not know how well they did relative to their peers, and therefore the experiment would not have accounted for the kind of learning our theory describes.

\section{Experiment - Results and Discussion}

Over all twelve experimental rounds, in around $52 \%$ of cases subjects playing a role of government officials indicated their willingness to accept bribes (50 instances out of 96). In 46 out of 96 responses (about 48\%), businessmen decided to hide half of their profit. Consequently, in 53\% of cases when profit was hidden, a businessman encountered an official who was willing to cooperate - clearly consistent with the random matching we employed. Out of twenty-six cases of an official accepting a payment from a businessman, two were discovered. Out of eight subjects playing the role of businessmen, one never hid his profit, while one decided to hide half of his profit in each round. Out of eight tax officials, two chose not to cooperate in any round, while two decided to cooperate in every round. Over the course of the experiment, an average subject acting as a tax official chose to accept the payment if offered in 6.25 rounds (the standard deviation was 4.95). An average subject acting as a businessman chose to hide half of his/her profit in 5.75 rounds (the standard deviation was 4.21). Average per round payoff of a subject playing the role of a businessman was 4.86 experimental hryvnias (with standard deviation of 0.47 ). Yet, half of businessmen managed to make more than five experimental hryvnias per round, suggesting that for them hiding part of the profit paid off. On average, a subject playing role of tax official made 1.22 experimental hryvnias per round (with standard deviation of 0.22 ). Five out of six officials who chose to accept bribes in at least one round managed to make more than one experimental hryvnia per round (the sixth one averaged one experimental hryvnia per round).

Figure 1 presents dynamics of the shares of businessmen hiding profit and officials accepting payments if offered. Figures 2 and 3 present information on actions and payoffs of businessmen and officials, respectively. 
Figure 1 Share of Businessmen Hiding Profit and Officials Cooperating

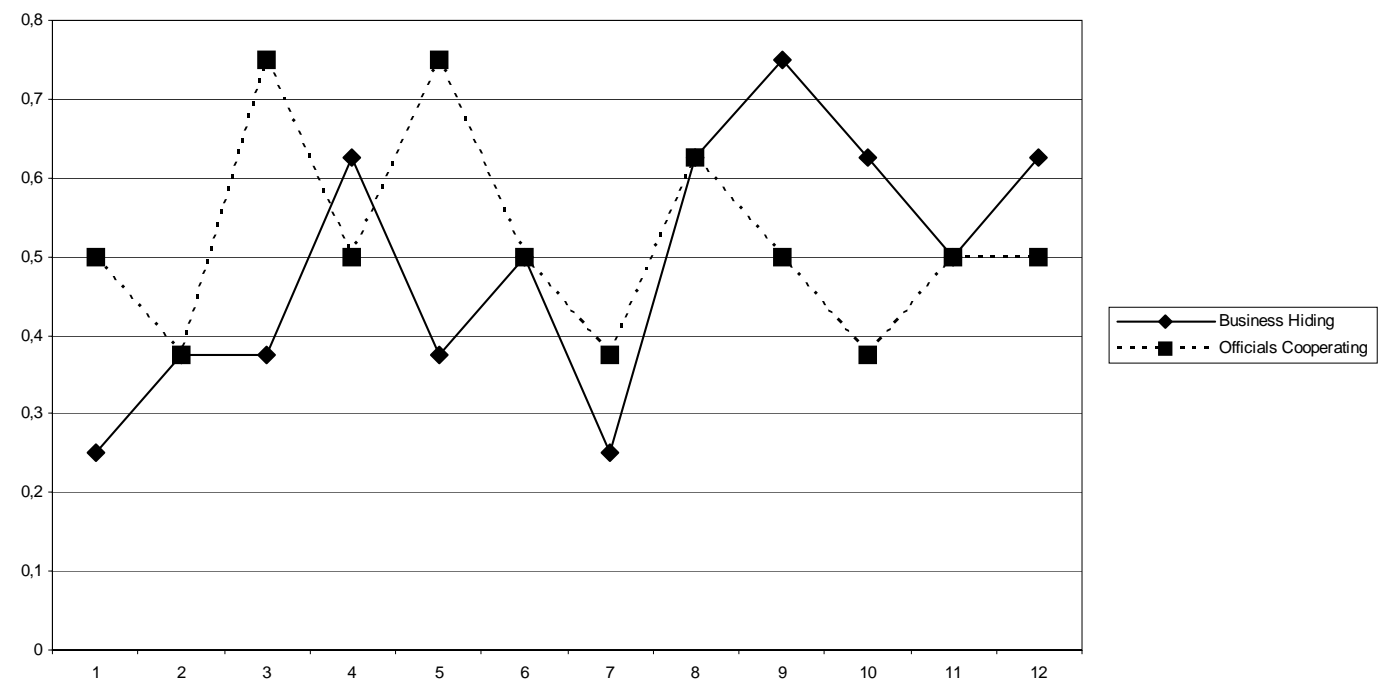

Figure 2 Businessmen's Actions and Payoffs

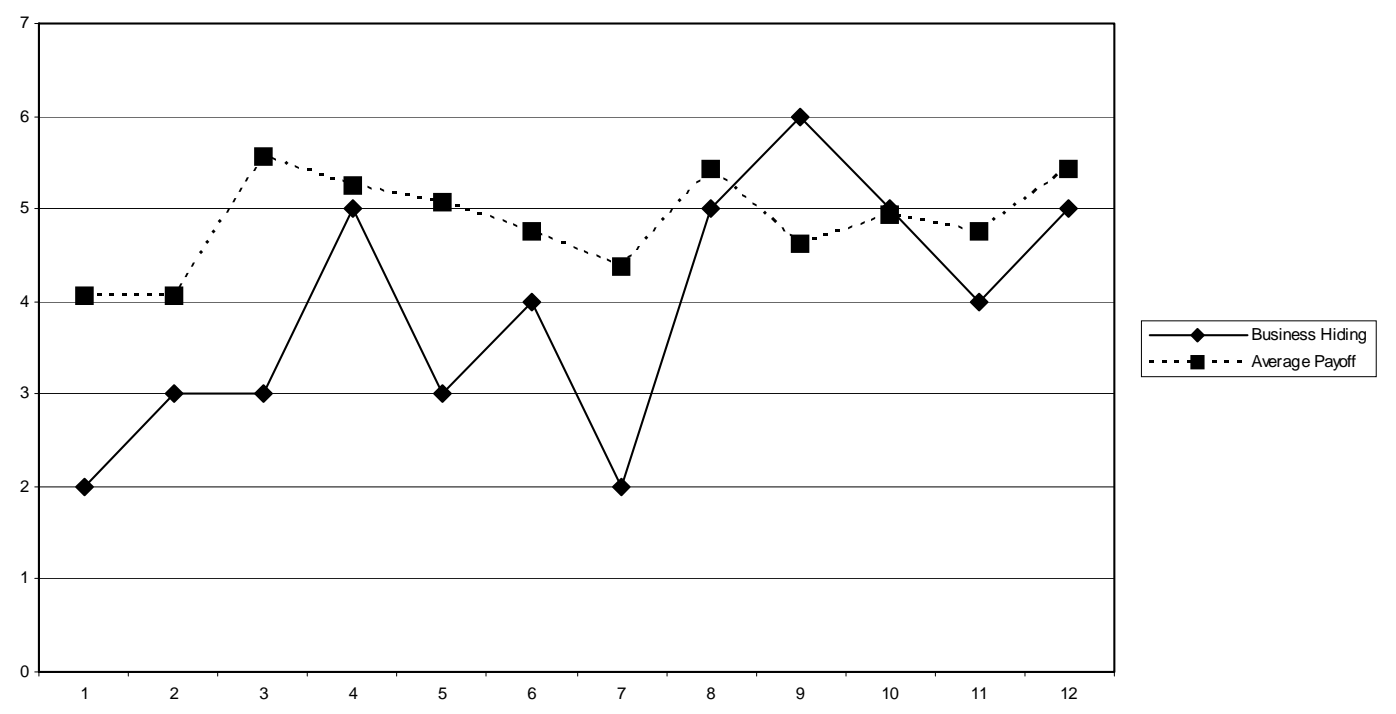

Note: this Figure represents the number of hiding businessmen subjects in each round, not the share, as Figure 1 
Figure 3 Officials' Actions and Payoffs

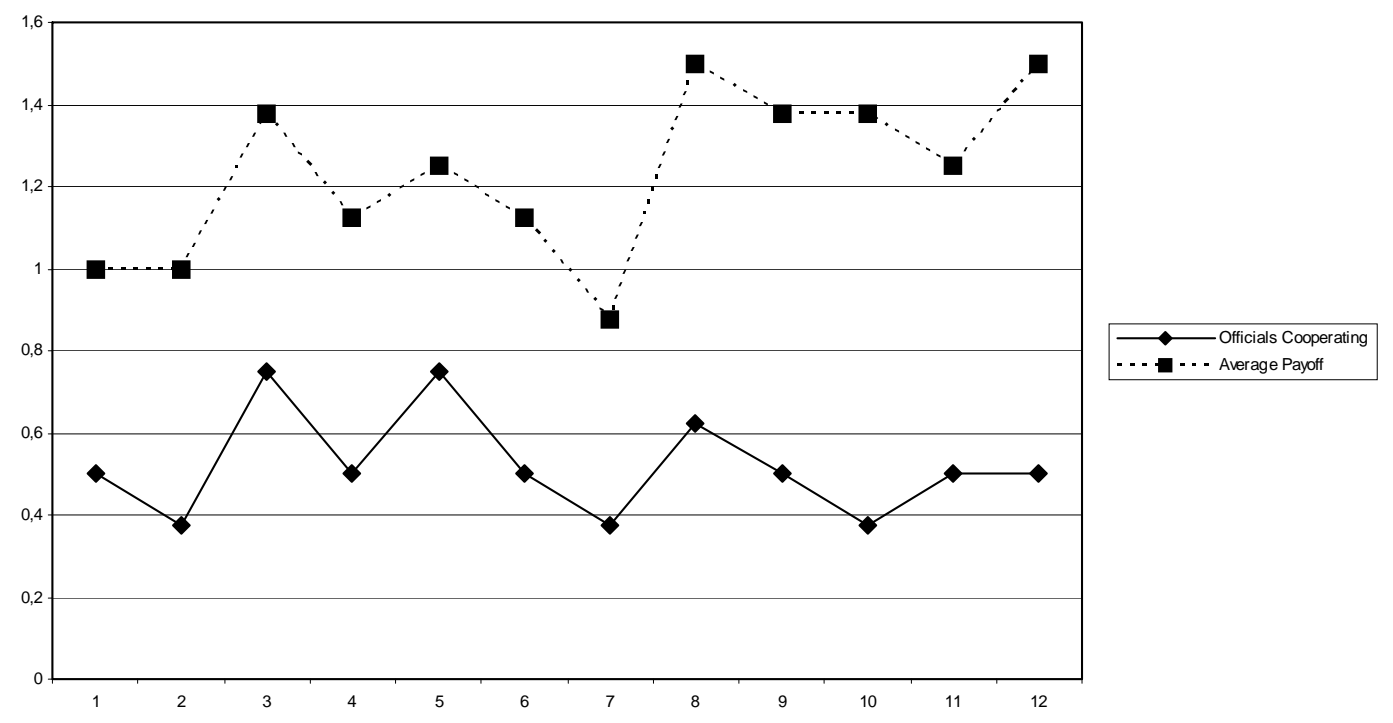

The figures show that during the third and the fifth experimental rounds the number of officials willing to accept the payment, if offered, has reached $\operatorname{six}^{11}$ (out of eight subjects). We can suggest that subjects playing the role of tax officials initially acted more or less consistently with our model's predictions. That is, the number of officials accepting bribes initially increased, as it was supposed to. Yet, following the fifth round the number of officials accepting payments decreased and only in eighth round did it reach five. More interestingly, the number of officials accepting bribes actually declined after the eighth round, when the number of businessmen hiding profit started to increase. An interesting observation about the number of businessmen hiding profit is that in several cases (after the first, seventh and eleventh rounds) this number increased even though the small number of officials willing to accept bribes suggested quite the opposite had to happen.

Since the declared emphasis of our experiment was a study of whether the tax evasion and bribery equilibrium can become wide-spread in the laboratory setting, we decided it was necessary to send messages to subjects about what was going on, as described in the previous section. After the fourth round, it was announced to everyone that in the last round of the experiment four out of eight tax officials chose to accept payment if offered. A simple simulation exercise based on (8) and (12) predicts that share of businessmen hiding profit should fall following this announcement, and gradually increase afterwards. The source of this increase is increasing share of officials accepting bribes. Businessmen acted according to this prediction for two rounds after the announcement. Officials initially reacted as expected - two more subjects chose to accept bribes in the fifth round. But after the sixth round share of bribe accepting officials decreased again, to jump abruptly between the seventh and the eighth rounds. After the eighth round a similar announcement was made. This time, the number of officials that chose to accept bribe in the preceding round was five. This is the

11 Note that two subjects acting as tax officials chose never to accept payments when offered. In discussions following the experiment, one of such subjects indicated she acted so in accordance to her moral principles. 
theoretical cut-off point, after which the number of profit-hiding businessmen should start increasing. In fact, we do observe an increase in the share of profit-hiding businessmen from $40.6 \%$ (over the first eight rounds) to $62.5 \%$ (over the last four rounds). This difference is statistically significant at $5 \%$ level for the simple two-tailed difference-in-means t-test (with the p-value of 0.0446). Unfortunately, we failed to observe convergence of shares of either businessmen or officials to either zero or one. This can be due to few subjects participating in the experiment, few rounds, framing effects, or lack of subjects' understanding of what was going on (economic experiments are run only sporadically in Ukraine) - we can only conjecture what happened.

While we cannot know for sure what drove each of the subject's decisions during the experiment, we can try to discuss the observed results in light of our model. We can definitely say that not all theoretical predictions have been realized during the experiment. Yet, we can also observe that experiment's results confirm some of the model's suppositions. This relates especially to those which concern the spreading of tax evasion and bribery across society. It appears that initially officials were quite eager to accept bribes, but after the fifth round the bribe-accepting activity has decreased. Probably, due to relatively few businessmen hiding profit, not all officials saw benefits from a potentially riskier action. In the third round, only three out of six officials who indicated they would accept a payment if offered encountered a businessman who implicitly offered them the payment by choosing to hide half of his profit. In the fifth round, this number was equal to two. As for the risk part of the game, we actually observe no cases of officials being discouraged by their bribe-taking being discovered.

Businessmen's actions seem closer to the model's predictions. When the game is played across society, the businessmen's incentives to hide profit depend on the share of officials willing to accept bribes: once the share of bribe-accepting officials reaches a certain number, the profit-hiding activity should become wide-spread. We see that once businessmen found out that this number has been reached (without actually knowing what this number is), they have increasingly started to hide their profit. The rounds after which announcements would be made have been predetermined, so it is not clear what would have happened should an announcement on the number of officials willing to accept bribes had been made after the third or the fifth round. An interesting and important fact is, however, that actions of businessmen and not of tax officials appear to have been the primary reason behind the increased shadow activity in our 'economy'.

Obviously, our theoretical model and experimental setting is a simplification of the game actually played between businessmen and supervising officials. Yet, we believe that we do preserve major features of such a game. Further, we have a reason to believe that certain features of our setup would tend to bias the results against us. Most importantly, random matching of businessmen with officials does not exactly correspond to the naturally occurring situations, and should provide less incentive for the 'cooperative' outcome (businessman hiding profit and official accepting bribe). We nevertheless observed such activity, even though not on very large scale. Also, the experimental setup follows a simultaneous decision game. We can suggest that in reality the game is more likely to be sequential, and we have indicated above that tax evasion and bribery equilibrium is the only one surviving subgame perfection refinement.

Finally, this experiment only offers a single treatment, with no variation in parameter values across rounds. Thus, our experimental setup can be modified in a number of ways. First of all, one can give up random matching of businessmen and 
officials. ${ }^{12}$ Second, by varying tax rate, officials' wage and probability of being caught, one can suggest a way to choose between available policy options to combat tax evasion and corruption. Generally, it has been suggested that to successfully fight these phenomena the government should decrease the tax burden on the enterprises, raise salaries of the supervising officials, and/or monitor them better. Experimental results may only provide a hint towards choosing among the above paths, but we could as well manage to rule out some of the options.

\section{Concluding Comments}

Studies of shadow economy usually assume that entrepreneurs are the ones having to hide their activity due to predatory behavior of the government officials. One however has to acknowledge that businesses might themselves benefit from being able to hide a portion of their profit from the authorities, and may even be willing to pay for such an opportunity. This transaction is likely to become possible when enforcement officials are themselves imperfectly monitored. This paper develops this alternative view at underreporting by offering a formal model and some experimental evidence from a transition country, Ukraine. We present a case for the claim that entrepreneurs may not necessarily be pure victims, and therefore contribute to establishment of the shadow economy. Our story can be claimed to ignore the fact that supervising officials have higher bargaining power than do entrepreneurs, which is a valid criticism of our approach. Thus, we develop a plausible alternative view, keeping in mind that the traditionally held one may also be correct.

In the theoretical part, we develop a very simple game between a businessman and a supervising official. The former has a choice of reporting his entire profit to the authorities or hiding part of the profit, while the latter can forget to report this violation in return for the bribe. We show that if the supervising official is imperfectly monitored and paid a low wage, a situation where the businessman underreports the profit and the official accepts bribe can become a Nash equilibrium of our game. Imperfect monitoring and low wages of government officials are general features of developing and transition economies, where shadow economic activities are extensive. We also show that the above-described equilibrium can spread across the society, provided sufficiently large share of officials are willing to accept bribes.

The game was put into an experimental setting, using parameter values which can be considered plausible for a transition or developing economy. The experiment was run in Kiev, Ukraine, and involved subjects from Ukraine, Belarus and Moldova. The emphasis of the experiment was on examining whether tax evasion and bribery equilibrium can become wide-spread. This was achieved through periodic announcements of the number of subjects acting as tax officials willing to accept bribe if offered. When this number reached the theoretical cutoff point after which the share of businessmen hiding profit should increase, this is precisely what we observed. Officials did not seem to act according to the model's predictions; yet, the number of profithiding businessmen was not announced in the experiment.

Even though only few of the theoretical predictions have been confirmed experimentally, and small number of subjects and few rounds did not allow us to reach convergence to either of the stable states our model predicts, one must understand that 12 It is not however clear how such a modification will allow us to study learning effects, as we did in this
experiment. 
our experimental setup includes certain features working against us. Most notable of those are random matching of businessmen and tax officials (in reality the interaction is more likely to be repeated); and modeling the game as the one with simultaneous decision making, while sequential setup seems more realistic. Thus, being able to observe some theoretical predictions fulfilled can be considered a success, given our setup. Future studies could modify our initial treatment to check for robustness of results reported here. It also appears interesting to conduct similar experiments in other developing and transition countries. It is not very clear, actually, how subjects in other countries will behave when put into a similar laboratory setting. As mentioned above, one tax evasion experiment conducted in both Albania and the Netherlands (Gërxhani and Schram, 2006) detected differences in subjects' behavior across countries; also, Torgler (2002) stresses importance of institutional and social factors in determining compliance with the tax law.

\section{References}

Abink K. and Hennig-Schmidt H. (2002), 'Neural versus Loaded Instructions in a Bribery Experiment', Bonn Graduate School of Economics Discussion Paper No. 23.

Abbink K. B. Irlenbusch and Renner E. (2002), 'An Experimental Bribery Game', Journal of Law, Economics and Organization, 18, 428-454

Acconcia A., D'Amato M. and Martina R.(2003), 'Tax Evasion and Corruption in Tax Administration', mimeo.

Blackburn K. and Forgues-Puccio G. F.(2005), 'Distribution and Development in a Model of Misgovernance', mimeo.

Chander P. and Wilde L.(1992), 'Corruption in Tax Administration', Journal of Public Economics, 49, 333-349

Feige E.L. (1997), 'Underground Activity and Institutional Change: Productive, Protective and Predatory Behavior in Transition Economies', in Nelson J.M, Tilley C., and Walker L (eds.), Transforming Post-Communist Political Economies, National Academy Press, Washington, D.C.

Fudenberg D. and Tirole J. (1991), Game Theory, The MIT Press, Cambridge

Gardner R. (1995), Games for Business and Economics, John Wiley, New York.

Gërxhani K. (2004), 'Tax Evasion in Transition: Outcome of an Institutional Clash? Testing Feige's Conjecture in Albania', European Economic Review, 48, 729-745

Gërxhani K. and Kuiper (2004), 'Tax Evasive Behavior and Gender in a Transition Country', mimeo

Gërxhani K. and Schram A.(2006), 'Tax Evasion and Income Source: A Comparative Experimental Study', Journal of Economic Psychology, forthcoming

Johnson S., Kaufmann D., Shleifer A. and Weitzman M.L. (1997), 'The Unofficial Economy in Transition', Brookings Papers on Economic Activity No. 2, 159-239

Johnson S., Kaufmann D. and Zoido-Lobaton P. (1998), 'Regulatory Discretion and the Unofficial Economy', American Economic Review, 88, 387-392

Johnson S., Kaufmann D., McMillan J. and Woodruff C. (1999), 'Why Do Firms Hide? Bribes and Unofficial Activity after Communism', EBRD Working Paper No. 42

Polinsky A.M., and Shavell S.(2001), 'Corruption and Optimal Law Enforcement', Journal of Public Economics, 81, 1-24 
Schneider F. and Enste D.(2000), 'Shadow Economies: Size, Causes and Consequences', Journal of Economic Literature, 38, 77-114

Torgler B.(2002), 'Speaking to Theorists and Searching for Facts: Tax Morale and Tax Compliance in Experiments', Journal of Economic Surveys, 16, 657-683

Trehub M. (2004), 'The Patterns of Tax Evasion in Russia: Evidence from Russian Longitudinal Monitoring Survey of Households', MA Thesis, EERC MA Program in Economics, Kiev, Ukraine. 


\title{
Appendix A - Experiment Instructions
}

\author{
Experiment Instructions
}

Your Role: Tax Official

You are about to participate in an economic experiment. You can make considerable amount of money, which will be paid to you in cash after the experiment is over. The amount of money you will make will depend on the actions you will take, as well as on those of your counterpart.

In this experiment you will pay a role of a tax official. In each round, you obtain the salary of 1 (one) experimental hryvnia. Each round, you are randomly assigned to inspect one business. In the course of inspection, a businessman (one of the subjects in this experiment) may offer you payment in the amount of 1 (one) experimental hryvnia. You have two actions available to you. You can choose to either accept or decline the payment if offered. Please make your choice by circling either "Accept" or "Decline" on the subject sheet.

A businessman you are randomly matched with may choose to underreport his actual profit. A payment to you will be offered only if the businessman chooses to underreport. No payment will be offered if the businessman chooses to report all the profit he received. If you decline the payment when offered, and also if no payment is offered, your payoff for the current round will be equal to 1 (one) experimental hryvnia - that is, you only get your salary.

If you choose to accept the payment and the payment is offered, you will obtain 1 (one) experimental hryvnia in addition to your salary. However, in this case there is $10 \%$ chance that this transaction will be discovered. If you are discovered to have accepted the payment from a businessman, your payoff for the current round will be zero. If you have accepted the payment and the transaction is not discovered, your payoff for the current round will be 2 (two) experimental hryvnias.

At the end of each round, your payoff will be communicated to you.

At the end of the experiment, your experimental hryvnias will be converted into real hryvnias at the exchange rate of 3 (three) experimental hryvnias per one hryvnia. In addition to that, you will be paid 3 (three) hryvnias irrespective of your actions during the experiment. 


\section{Experiment Instructions}

\section{Your Role: Businessman}

You are about to participate in an economic experiment. You can make considerable amount of money, which will be paid to you in cash after the experiment is over. The amount of money you will make will depend on the actions you will take, as well as on those of your counterpart.

In this experiment you will pay a role of a businessman. In each round, your business makes profit in the amount of 10 (ten) experimental hryvnias. You have two actions available to you. You can disclose to the tax authority either your entire profit, or only half of your profit. Please make your choice by circling either "Entire Profit" or "Half Profit" on the subject sheet.

In case you disclose the entire profit to the tax authority, you have to pay tax on it at the rate of $50 \%$. Thus, if you choose to disclose the entire profit to the tax authority, you pay 5 experimental hryvnias in taxes, and your payoff for the current round will be 5 experimental hryvnias.

In case you choose to disclose only half of the profit to tax authorities, you only pay 2.5 experimental dollars as tax $\left(0.5^{*} 5\right)$, but your business is inspected by the tax official, who perfectly observes that your profit was 10 experimental hryvnias, not 5 as you have reported. Tax official is one of the subjects of the experiment, and you are randomly matched with a tax official. The tax official's salary is 1 (one) experimental hryvnia for each round.

The tax official has two options to choose from. He can either cooperate with you or not cooperate with you. If you choose to disclose half of your profit and the tax official chooses to cooperate with you, the tax official accepts payment in the amount of 1 (one) experimental hryvnia from you, and does not report your violation. Thus, you payoff in this case will be equal to 6.5 experimental hryvnias, as follows: 2.5 hryvnias as post-tax profit of the disclosed part of your profit plus 5 hryvnias of the undisclosed part of your profit minus 1 hryvnia as payment to the tax official.

If, however, the tax official decides not to cooperate with you and you try to hide part of your profit, the undisclosed part of your profit is confiscated, so your payoff will be 2.5 experimental hryvnias. The tax official DOES NOT obtain any part of the confiscated profit.

At the end of each round, your payoff will be communicated to you.

At the end of the experiment, your experimental hryvnias will be converted into real hryvnias at the exchange rate of 3 (three) experimental hryvnias per one hryvnia. In addition to that, you will be paid 3 (three) hryvnias irrespective of your actions during the experiment. 


\section{Appendix B - Subject Sheets}

Subject $\mathrm{O}-$ (subject number)

Table B.1 Official's Subject Sheet

\begin{tabular}{|c|c|}
\hline Round 1 & Round 2 \\
\hline If a payment is offered to me, I will & If a payment is offered to me, I will \\
\hline Decline & Decline \\
\hline Your Payoff: & Your Payoff: \\
\hline Round 3 & Round 4 \\
\hline If a payment is offered to me, I will & If a payment is offered to me, I will \\
\hline Decline & Decline \\
\hline Your Payoff: & Your Payoff: \\
\hline Round 5 & Round 6 \\
\hline If a payment is offered to me, I will & If a payment is offered to me, I will \\
\hline Decline & Decline \\
\hline Your Payoff: & Your Payoff: \\
\hline Round 7 & Round 8 \\
\hline If a payment is offered to me, I will & If a payment is offered to me, I will \\
\hline Decline & Decline \\
\hline Your Payoff: & Your Payoff: \\
\hline Round 9 & Round 10 \\
\hline If a payment is offered to me, I will & If a payment is offered to me, I will \\
\hline Decline & Decline \\
\hline Your Payoff: & Your Payoff: \\
\hline Round 11 & Round 12 \\
\hline If a payment is offered to me, I will & If a payment is offered to me, I will \\
\hline Accept & Decline \\
\hline Your Payoff: & Your Payoff: \\
\hline
\end{tabular}




\section{Subject $B-$ (subject number)}

Table B.2 Businessman's Subject Sheet

\begin{tabular}{|c|c|}
\hline \multirow{2}{*}{$\begin{array}{l}\text { Round } 1 \\
\text { In this Round, I would like to disclose }\end{array}$} & \multirow{2}{*}{$\begin{array}{l}\text { Round } 2 \\
\text { In this Round, I would like to disclose }\end{array}$} \\
\hline & \\
\hline Entire Profit & Entire Profit \\
\hline Your Payoff: & Your Payoff : \\
\hline Round 3 & Round 4 \\
\hline In this Round, I would like to disclose & In this Round, I would like to disclose \\
\hline Entire Profit & Entire Profit \\
\hline Your Payoff : & Your Payoff : \\
\hline Round 5 & Round 6 \\
\hline In this Round, I would like to disclose & In this Round, I would like to disclose \\
\hline Entire Profit & Entire Profit \\
\hline Your Payoff : & Your Payoff: \\
\hline Round 7 & Round 8 \\
\hline In this Round, I would like to disclose & In this Round, I would like to disclose \\
\hline Entire Profit & Entire Profit \\
\hline Your Payoff : & Your Payoff: \\
\hline Round 9 & Round 10 \\
\hline In this Round, I would like to disclose & In this Round, I would like to disclose \\
\hline Entire Profit Half Profit & Entire Profit Half Profit \\
\hline Your Payoff : & Your Payoff: \\
\hline Round 11 & Round 12 \\
\hline In this Round, I would like to disclose & In this Round, I would like to disclose \\
\hline Entire Profit $\quad$ Half Profit & \\
\hline Your Payoff : & $\begin{array}{l}\text { Entire Profit } \\
\text { Your Pavoff: }\end{array}$ \\
\hline
\end{tabular}

